\title{
Rate filing policies for inland water transportation: an experimental approach
}

\author{
James T. Hong* \\ and \\ Charles R. Plott**
}

This study uses laboratory experiments to explore the possible consequences of a proposed rate publication policy for the domestic, dry bulk commodity transportation industry on inland waterways. The central problem is to determine the effects of a requirement that a carrier must file a proposed rate change with the Interstate Commerce Commission at least fifteen days before the rate change is to become effective. The study concludes that in laboratory markets that have many of the essential economic features of the barge industry, rate filing policies cause higher prices, lower volume, and reduced efficiency, and they hurt the small participants. Claims that rate filing policies would improve the operations of markets with these economic features are not supported by the laboratory research conducted to date.

\section{Introduction}

- Within recent years several programs of rate publication have been proposed for the transportation of domestic dry bulk commodities on inland waters (referred to here as the barge industry). At issue in such programs is a requirement that if a "for-hire" carrier wishes to change its rates, it must file with the ICC before the rate change is to become effective (typically a fifteen-day period is proposed). Currently, rates on tows are set through individual negotiations, and the terms of each contract are, necessarily, known only to the contracting parties.

The full consequences of a rate filing policy are unknown. Plausible theoretical arguments can be made on both sides of the policy argument. When existing theory does not yield a definitive answer, one can usually turn to previous experiences with policies, but in this case we are aware of no industrial case study that would provide direct evidence on either side of the controversy. Some experience with the effects of price posting policies has been gained by studying the behavior and performance of laboratory markets. In particular, studies by Williams (1973) and Plott and Smith (1978) provide instances where markets characterized by posted price policies are less efficient and

* California Institute of Technology. In July 1978 the career of this gifted graduate student was tragically shortened by a swimming accident that left him totally disabled. C.R.P.

** California Institute of Technology.

Research support supplied by the U.S. Department of Transportation and the National Science Foundation is gratefully acknowledged. The authors wish to acknowledge the help of research assistants Ed Rea and Brian Chaney. We would also like to thank Dr. John W. Snow, who suggested the importance of the topic. 
induce higher prices than do oral auction markets, although whether this persists at equilibrium levels is unknown.

Any extrapolation from published experimental results to the barge industry itself is open to two potential criticisms, the reasonableness of which this study was designed to assess. First, the barge industry has several prominent economic features that are not incorporated in existing laboratory market studies. Examples include the relative sizes of buyers and sellers, the demand and supply elasticities, and the cyclical nature of demand. Naturally, we can never be certain that all the important features have been included in the present design. If something important has been misspecified or omitted, then the observed behavior of the laboratory market may not extend to the barge industry, and additional appropriately modified experiments can be conducted as checks on our conclusions. The second potential criticism is that the effects of price posting in laboratory studies have only been measured relative to the performance of oral auction markets. Since auction markets differ from the negotiated price markets of the industry, the relevance of the comparison can be questioned.

The article is organized as follows. In Section 2 the experimental design and procedures are reviewed. The parameter values for all experiments are given in Section 3. Then, in Section 4, the parameter values of the laboratory market are compared with those of the industry. The experimental results are presented in Section 5, and Section 6 summarizes the conclusions.

\section{Experimental design}

- A total of 33 subjects agreed to participate in experiments for three hours per night for four nights. They were told that they would earn approximately $\$ 80$ each over the four-night period. Subjects included engineers from Jet Propulsion Laboratory, Caltech faculty members, secretaries, housewives, and graduate students in engineering, business, and law, and some Caltech undergraduates.

Subjects were randomly given a subject number which keyed them to an incentive structure for each of four experimental sessions. A different experimental session was held each night. Instructions were read, and a comprehension test on the use of the forms was given on the first night. (See Appendix.) Earnings were paid in cash at the end of the last session. Subjects were told that only those who participated in all sessions would be paid unless they found someone to replace them.

Experimental sessions were held in Baxter Hall at the California Institute of Technology from 7:00 p.m. to 10:00 p.m. Tuesday, Wednesday, Thursday, and the following Monday. Subjects were assigned randomly to faculty offices and, for the most part, were alone in the office for the duration of the experiment. Exceptions occurred when a spouse or a friend would show up with a sandwich. Some subjects brought additional work or books with them which occupied their time during "slack" periods. Contact between subjects was minimized between session periods, although face-to-face chatter did occur occasionally when subjects met at the restroom, fountain, or Coke machine. Some subjects knew other subjects, but experimenter observations and postexperimental debriefings substantiate the conclusions that little or no contact existed between subjects aside from that permitted by the experimental design. ${ }^{1}$

Each experimental session was organized into a series of market periods or days. For each period each subject buyer (seller) had a schedule of limit prices, which dictated the maximum (minimum) prices the subject could pay (receive) for each unit. All profits

${ }^{1}$ There is one major exception which resulted from the failure of a subject to return after the first evening. To preserve the proper number of subjects, we permitted the wife of a subject to take the place of the missing individual. Subsequent data analysis, previous experiments, and subsequent experiments indicate that this substitution had no measurable effect. 
made by buying (selling) below (above) the limit price were the subject's to keep. ${ }^{2}$ These schedules differed among subjects and could differ between periods for the same subject. Discussions of limit prices were prohibited. Collusion and side payments were strictly forbidden.

Each subject was seated in an office with a phone. Before the subject was a list of all other subjects and their phone numbers and a pad of incentive sheets stapled together so the subject could see the redemption values or cost for only the past and the immediately upcoming period. When the period opened (this was signaled by a loud horn), each subject was free to call any other subject and engage in whatever transactions possible. Conversations could range over any topic whatsoever other than price collusion or profit splitting. Subjects were free to reveal, lie, or say nothing about the deals made with other subjects. No one could buy and resell units to other subjects. Whenever a deal was made in the laboratory markets, both parties in effect signed a contract by repeating a short ritual over the phone and recording the terms in their individual record sheets. Periods lasted 15 minutes for the first few and then 12 minutes each after that. At the end of a period, signaled by a horn, all trading and telephoning stopped. Subjects calculated their profits and examined the incentive sheet for the next period. After the final period, subjects calculated their total profits and left all materials with the experimenter when they went home for the evening.

Two different modes of organization were studied. Experimental sessions 1 and 4, held respectively on the first and last evenings, involved negotiated price markets. Experimental sessions 2 and 3, held respectively on the second and third nights, involved posted price markets. Aside from these different modes of organization, the experimental settings are substantially identical.

The negotiated price markets can best be understood by contrast with an auction market. In the latter all bids, offers, and contracts are observed by all market participants. Negotiated price markets differ since only the two parties engaged in negotiation can be fully aware of the terms discussed and agreed upon. They may tell others about contract terms, but the quality of such information is subject to no controls. Furthermore, information about market transactions is costly to obtain in a telephone market, since the time used to gather information could be used for buying and for selling.

The posted price markets differed in one major respect. After sellers studied the cost schedule for an upcoming period, each would privately post with the experimenter the price(s) she/he would charge during the upcoming period. Once all sellers had registered their prices with the experimenter (by phone or by a carrier that circulated to gather prices), a price list was photocopied and distributed to all subjects before a period opened. When the period opened, at the sound of a horn, any subject was free to call any other subject and make a purchase or sale at the price posted by the seller involved in the deal.

\section{Laboratory market parameters}

An overview of the parameters for all experimental sessions is contained in Table 1. The market organizations in sessions 1 through 4 were negotiated prices, posted prices, posted prices, and negotiated prices, respectively. The demand and supply functions can be explained by reference to the functions used in the first periods of session one, the "basic" market demand and supply functions $D(x)$ and $S(x)$ shown in Figure 1. To minimize any possible effects of expectations from session to session, demand and supply functions differed by a constant across sessions. In all experiments demand was held initially constant through period four, shifted upward by $\$ .60$ for four periods, and

\footnotetext{
${ }^{2}$ See Smith (1976) and Plott (1979) for a discussion of limit prices and induced preferences.
} 
TABLE 1

Overview of Laboratory Market Parameters

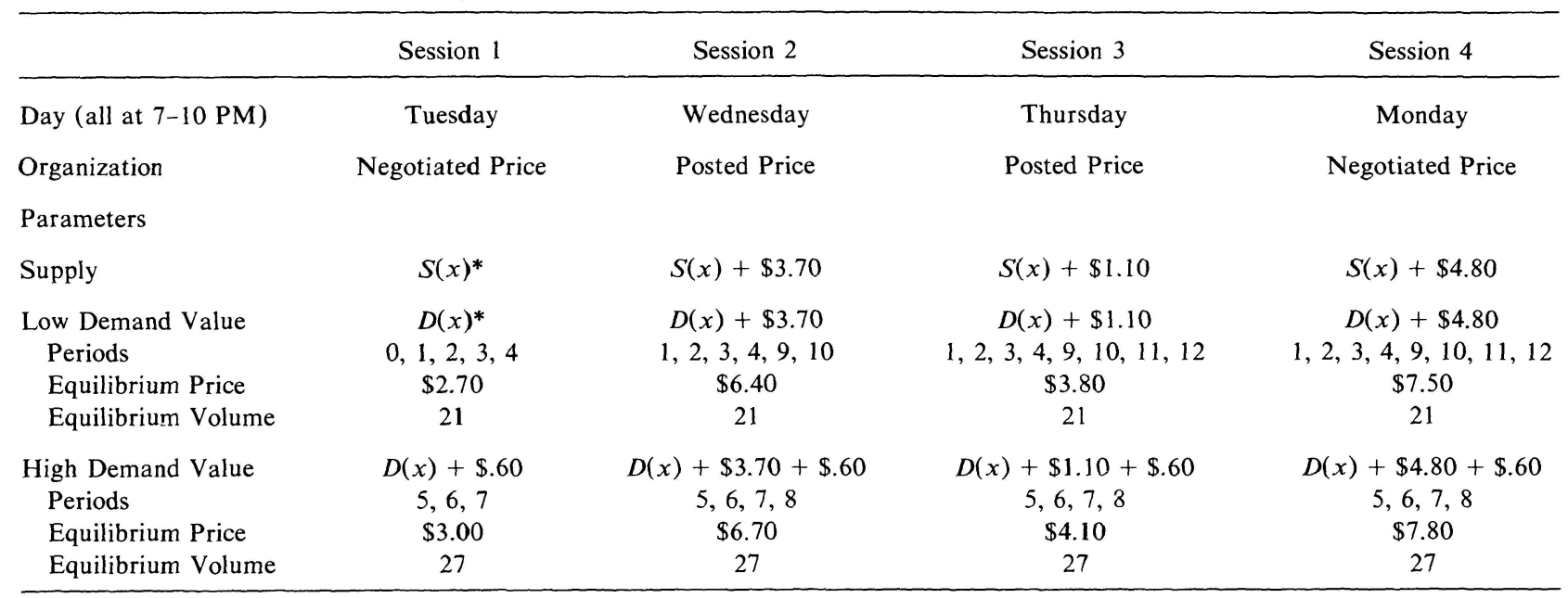

* The functions $S(x)$ and $D(x)$ are graphed in Figure 1. 
FIGURE 1

MARKET DEMAND AND SUPPLY

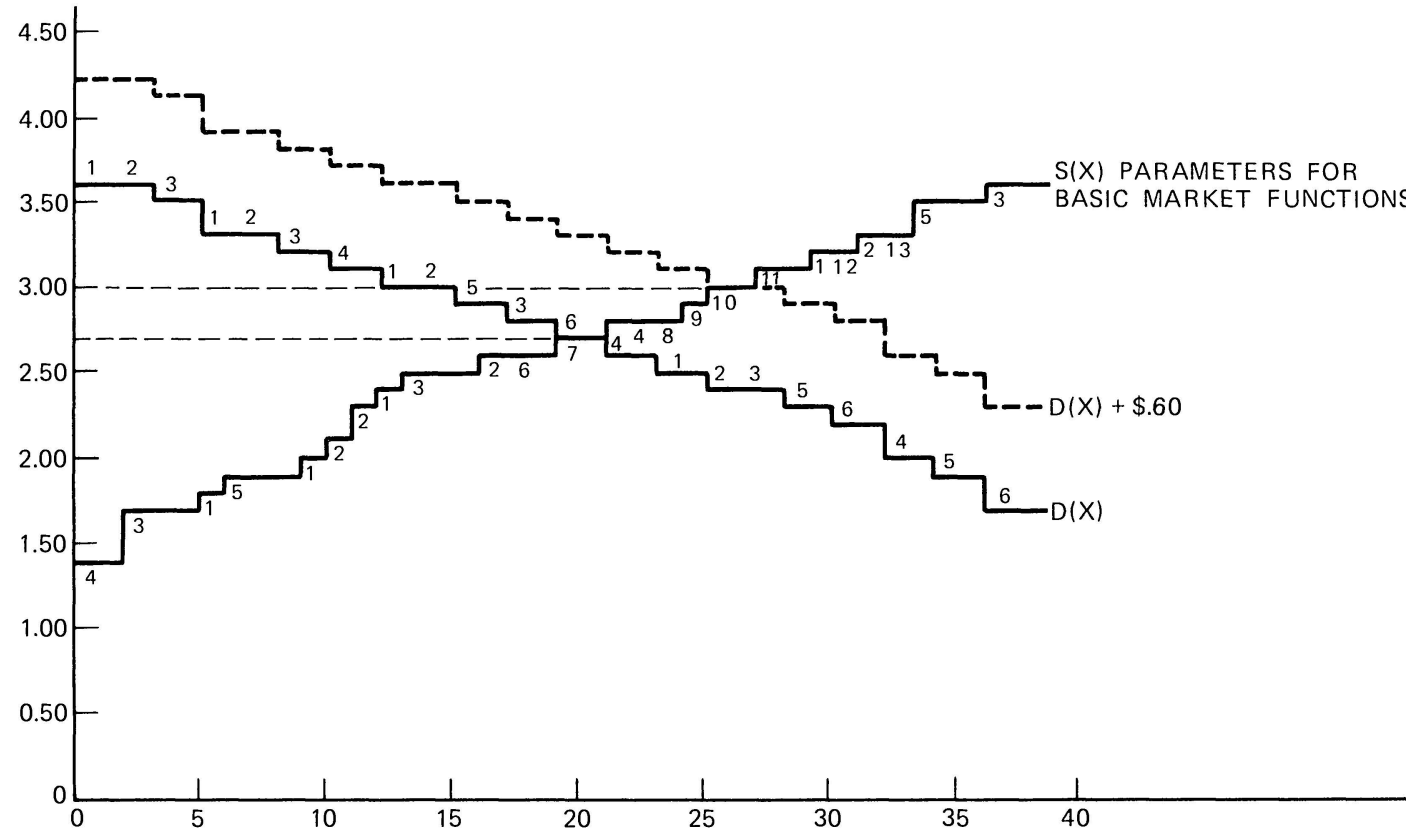

returned to the original position until the experiment terminated. ${ }^{3}$ Within a session the equilibrium prices in the low demand and high demand periods differed by $\$ .30$, and the equilibrium volumes were 21 units and 27 units, respectively. Across sessions the predicted equilibria differed by the constant shift parameter.

Thirteen different individual supply functions were distributed among 22 suppliers in any given period of any session. Thus weighting each of these functions by the number of suppliers holding it and then summing across functions yield the market supply function. The numbers below the market supply function $S(x)$ in Figure 1 indicate the appropriate individual supply schedule to which units at that value belong. Thus, the marginal cost schedule implicit in schedule 1 is $\$ 1.80, \$ 2.00, \$ 2.40$, and $\$ 3.20$ for units one through four, respectively. Each of the 13 functions can be deduced from $S(x)$ in a similar fashion. For example, the holders of schedule 7 are the marginal sellers during low demand periods, and those holding schedules 8 through 13 are extra marginal in these periods.

Six different individual demand schedules were distributed among eleven different demanders. The value of each of these individual functions can be obtained from the aggregate demand $D(x)$ as follows. Above the aggregate in Figure 1 are numbers that indicate the individual demand function that has a limit price at that value. Thus individual demand schedule 1 has one unit at each of the limit price levels $\$ 3.60, \$ 3.30$, $\$ 3.00$, and $\$ 2.50$. Other functions can be deduced similarly.

During a given market session agents did not have the same individual schedule in all periods. Instead the schedules were rotated so that the aggregate demands and supplies were constant; but the situation from an agent's point of view was changing slightly from

${ }^{3}$ The exception is session 1 , in which demand was initially held constant for five periods and shifted up for three and then the experiment ended. The extra period in the first part of this session is listed as a period 0 and was included to allow for learning about the technology of trading, the accounting rules, etc., which would be used in all subsequent sessions. 
period to period. The word "slightly" is used because "small" agents, as described in the next section, remained small and large ones remained large throughout a session. ${ }^{4}$

\section{Comparison of the laboratory market with the barge industry}

- Grain traffic along the upper Mississippi River and Illinois Waterway during the Autumn of 1970 was chosen as the subject market for the study. This market constitutes about $70 \%$ of all annual grain traffic and $35 \%$ of all annual dry bulk traffic in the United States excluding traffic along the Pacific coast. ${ }^{5}$ The year 1970 was chosen because it has features typical of historical trends and because the data are available. Grain was chosen because the product is relatively homogeneous and thus is not characterized by a great number of special and idiosyncratic features that would complicate an experimental design. We chose to study traffic during the Autumn since it is during this period that the industry is most active and is required to respond to changing market forces. The particular location of the industry was chosen for the same reasons. Thus we chose a relatively uncomplicated subsection of the barge industry that accounts for a large portion of the industrial traffic.

Once we selected the section of the industry, we had three problems to solve. First, the relevant shapes of the market demand and supply functions had to be determined. Second, the distribution of firm sizes, costs, and demand characteristics had to be estimated. Since the data were limited to those generated in a single year, standard econometric techniques could not be applied. We relied on such sources and judgments that we could find. Third, we had to construct a "scaled down" industry that captured most of the important features of the actual industry.

The following transformation expands our laboratory market to industrial size:

$$
\begin{aligned}
\text { one subject } & =4 \text { firms; } \\
\text { one period } & =2 \text { weeks; } \\
\text { one unit } / \text { period } & =1 / 2 \text { tow; } \\
\text { one tow } & =19.5 \text { million ton miles grain per month; and } \\
\text { one tow per month in study region } & =1 \text { boat's capacity in study region } \\
& =5 \text { boats' capacity in all regions. }
\end{aligned}
$$

a Basic economic conditions. Most observers of the barge market, whether they are in government or in the industry, agree that both the demand function and the supply function in the dry bulk commodities' barge market are relatively "flat." On the demand side this is no doubt a result of the existence of substitute transportation modes, and on the supply side it is a result of the ease of entry.

Ferguson et al. (1975) used a demand elasticity of two, but noted that an estimate as high as 3.9 was also obtained. The former was for all dry bulk, and the latter was for coal. Since the price of grain is less than that of many regulated goods and oil but is more than the price of coal, one would expect its elasticity to be bounded by the numbers 2 and 3.9 if the demand slopes are similar. Demand exhibits a pronounced seasonal component. During October and November, grain traffic resulting from Northern harvests becomes very heavy. Since prices of substitute transportation sources, truck and rail, are fixed, there is no reason to assume that the change in demand significantly

\footnotetext{
${ }^{4}$ The rotation schedule is available in Hong and Plott (1977).

${ }^{5}$ These figures reflect the percentage of total, selected dry bulk ton miles excluding shell, gravel, and rocks, and they are derived from Table II-B-1 of Smith (1976). The 70\% figure includes the data from unspecified months.
} 
changes the slope of demand. Thus we hypothesize that demand is elastic and relatively constant throughout the year except for the months of October and November when there is a substantial increase in demand.

Less is known about the slope of the supply function, but it has received attention in Howe et al. (1969). Barges can be leased and boats can be obtained at a minimal capital outlay for operation at a small scale. In addition, evidence of economies of scale has been detected. The shifting demand for grain traffic in the study region provides some information about the slope of the supply function. A difference in volume from an August-September average of 1.18 million tons to an October volume of 1.625 million tons is accompanied by a shift in price from an average of 2.725 mills/ton mile to 2.95 . This implies a possible supply elasticity of 4.57 [since $\Delta X / \Delta P \cdot P / X=(.445 / .225)(2.725 /$ $1.18)=(1.978)(2.309)=4.57]$ in the range of equilibrium and a supply curve slope $(\Delta P / \Delta X)$ of .51 in these units. The fact that this seasonal component is fully anticipated as it occurs every year helps support an assumption that long-run supply behavior is being revealed about the "upper portions" of the supply function.

Cost information helps give some feeling for the overall situation. Most estimates of the costs of water transport for this period are around three mills per ton mile (see Carr (1969), for example). Such estimates of line-haul costs were derived for the regulated firms reported in Gill and Whitten (1976). ${ }^{6}$ These costs ranged from 1.35 to about 5 mills per ton mile. These estimates, together with the fact that one mill was a lower limit on recorded prices (Friedlaender, 1969), lend support to the hypothesis that the supply function is bounded from below within the 1-1.5 mill range. If we further assume that these low per unit variable costs were characteristic of the larger, more efficient firms with per unit overhead spread over a large number of units, the numbers also provide an upper bound estimate of the lowest points on the supply function.

These estimates of properties of the demand and supply functions can be used to evaluate the parameters of the laboratory experiment when the latter are scaled to industrial size as shown in Figure 2 in the concluding section. The curve $D D$ is the laboratory market demand during low demand months ( 2 periods $=1$ month $)$, and $D^{\prime} D^{\prime}$ represents the two high demand months. The curve $S S$ is the laboratory supply function with the units scaled and aggregated into months. Price and volume during the months of August and September are "close" to the theoretical equilibria of the laboratory market with $D D$ as the specified demand function. The price-volume pair in October is close to the laboratory model with $D^{\prime} D^{\prime}$ as the specified demand function. The relationship between the experimental parameters and the market aggregates is further revealed by the November and December data. Demand remains high during November (perhaps approximated by $D^{\prime} D^{\prime}$ ), but the supply function shifts back as barges are used for storage. The fall in quantity and increase in price as shown for November should therefore be expected. Supply remains short in December when demand slips back to normal (assumed to be $D D$ ), and the lowered price-quantity pair shown for December is the result. Supply begins to return to normal in January and February. The relationships seem to remain relatively stable throughout the remainder of the year. The laboratory market involves two months of normal demand (August and September) followed by two months of high demand (two Octobers) and then two months of normal demand (January and Feburary).

The demand and supply slopes of the laboratory parameters are well within the ranges specified for the industry. The theoretical elasticity of demand is approximately 3 near the equilibrium, and the theoretical elasticity of supply is 4.87 . The lower limit on supply price of 1.4 and the equilibrium values are all close to those of the industry for this period of time.

\footnotetext{
${ }^{6}$ The report gives both accounting data and a formula for computing line-haul costs. These estimates result from an application of the method to the individual firm data they report.
} 


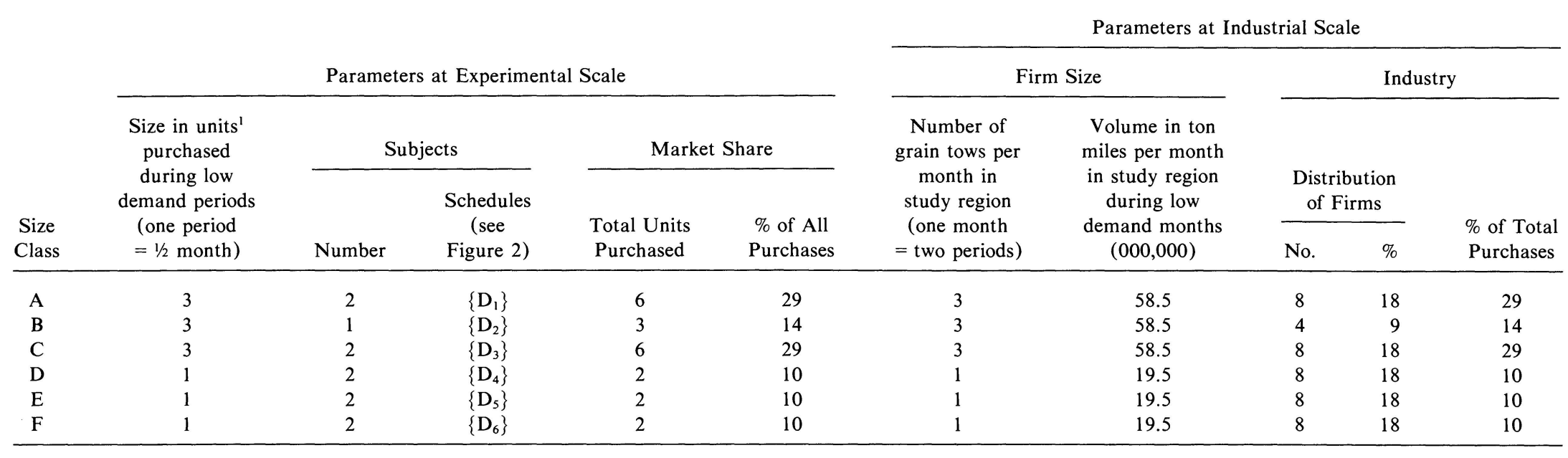

${ }^{1}$ These are equilibrium market purchases deduced from an application of competitive market theory. Other measures of size yield comparable percentage figures when applied uniformly across subjects. 
Industrial organization. During the period, between 50 and 60 shippers were in operation. They were fairly evenly divided between large and small shippers with the larger ones being about three times the size of the smaller. The exact number and sizes of shippers are not recorded so that these estimates were provided by carriers. The opinions of several individuals were sought, and they were all in general agreement.

As shown in Table 2, the laboratory market at industrial scale has 44 shippers with the largest $45 \%$ accounting for $72 \%$ of the grain business. Large firms are all about the same size. Small firms are also all about the same size, and each of them is about one-third the size of a large firm. These figures are similar to the opinions of industrial experts.

Comparisons between the structure of supply in the laboratory market and the supply structure of the barge industry can be made from Table 3 . The 22 subjects correspond to 88 firms at industrial scale, while according to the DOT (1973), the industry had 93 firms. Size distribution and market share comparisons are complicated because many firms operate in several areas in addition to the study region, and size data are available only at the firm level. In expanding the laboratory market to industrial scale we assumed that a capacity of one boat in the grain business in the study region implied a capacity of five boats in total for all users and all regions. ${ }^{7}$ We have thus assumed that the size distribution of the industry applies to this market.

One discrepancy between the actual market and the laboratory market seems to occur with the number of large firms. Nine percent of the firms are in the class of largest firms in the laboratory market, and only $2 \%$ were detected in this class from the listings in the DOT study (1973). In this instance we think the estimates derived from the DOT are too low, as subsidiaries are reported there as independent firms and the methods used in the DOT study did not anticipate this possibility. Thus, the proportions as represented in the laboratory market may be more accurate than they appear.

Prices in the industry are set as a result of individual negotiations, which are private. Frequently negotiations are made by phone with contracts signed by mail. Information about contract prices and contract opportunities differs among individuals and firms, depending upon their situation and their efforts to obtain information. The organization of negotiated price sessions in the laboratory market was an attempt to capture these features. Negotiations were bilateral and by phone. Information about contracts was costly. With so many participants, lines were frequently busy, and if a subject used the phone to negotiate or to seek information, s/he was forgoing opportunities to make contact with those who wished to trade. Thus, information conditions concerning price patterns in the laboratory market were not at all perfect. Some subjects had absolutely no idea about the price deals other subjects were able to get.

The posted price laboratory markets represented the proposed policy for the barge industry. The policy would require carriers to post their prices with the ICC from 1530 days before a price change. Information conditions in the laboratory market were probably much better than those that one could anticipate from the policy applied to the industry. All participants were made aware immediately, accurately, and costlessly of all price changes in the laboratory market. In this sense the laboratory posted price markets were free of many of the problems that might occur in actual practice.

\section{Experimental results}

The results are easy to summarize. The posted price policy causes higher prices, reduced volume, and efficiency losses. Furthermore, the posted price policy works to the

\footnotetext{
${ }^{7}$ Recall that our region accounts for only about $35 \%$ of all annual dry bulk traffic in the United States excluding the Pacific coast.
} 
TABLE 3 A Comparison of Actual Experimental Model Parameters, the Parameters at Industrial Scale, and Industry Statistics: The Supply Side

\begin{tabular}{|c|c|c|c|c|c|c|c|c|c|c|c|c|c|c|c|c|c|}
\hline \multirow{4}{*}{$\begin{array}{l}\text { Size } \\
\text { Class }\end{array}$} & \multicolumn{5}{|c|}{ Parameters at Experimental Scale } & \multicolumn{6}{|c|}{ Distribution of Firms } & \multicolumn{6}{|c|}{ Rough Estimates of Industrial Statistics } \\
\hline & \multirow{3}{*}{$\begin{array}{l}\text { Size in } \\
\text { units } 1 \text { sold } \\
\text { during low } \\
\text { demand } \\
\text { periods } \\
\text { (one period } \\
=1 / 2 \\
\text { month) }\end{array}$} & \multirow{2}{*}{\multicolumn{2}{|c|}{ Subjects }} & \multirow{3}{*}{\multicolumn{2}{|c|}{ Market Share ${ }^{2}$}} & \multicolumn{3}{|c|}{ Firm Size } & \multirow{2}{*}{\multicolumn{3}{|c|}{ Industry }} & \multirow{2}{*}{\multicolumn{3}{|c|}{ Derived from DOT Study $(1973)^{3}$}} & \multirow{3}{*}{\multicolumn{2}{|c|}{\begin{tabular}{cc}
\multicolumn{2}{c}{ Judgments of Indust } \\
Firm \\
size in \\
terms of $\quad$ Number \\
number & of \\
of boats & Firms
\end{tabular}}} & \multirow{3}{*}{$\begin{array}{c}\% \text { of } \\
\text { Grain } \\
\text { Marke }\end{array}$} \\
\hline & & & & & & \multirow{3}{*}{$\begin{array}{l}\text { Number } \\
\text { of grain } \\
\text { tows per } \\
\text { month in } \\
\text { study } \\
\text { region } \\
\text { (one } \\
\text { month } \\
=\text { two } \\
\text { periods) }\end{array}$} & \multirow{3}{*}{$\begin{array}{l}\text { Average ton } \\
\text { miles of } \\
\text { grain per } \\
\text { month in } \\
\text { study region } \\
\text { during low } \\
\text { demand } \\
\text { months } \\
(000,000)\end{array}$} & \multirow{3}{*}{$\begin{array}{c}\text { Total } \\
\text { number } \\
\text { of boats } \\
\text { in all } \\
\text { regions }\end{array}$} & & & & & & & \multirow{2}{*}{$\begin{array}{c}\text { Judgme } \\
\text { Firm } \\
\text { size in } \\
\text { terms of } \\
\text { number } \\
\text { of boats }\end{array}$} & & \\
\hline & & & & & & & & & \multicolumn{2}{|c|}{$\begin{array}{c}\text { Number of } \\
\text { Firms }\end{array}$} & \multirow{2}{*}{$\begin{array}{l}\% \text { of total } \\
\text { grain } \\
\text { tonnage in } \\
\text { study area } \\
\text { (\% total } \\
\text { grain tows } \\
\text { in study } \\
\text { region) }\end{array}$} & \multirow{2}{*}{$\begin{array}{l}\text { Firm size } \\
\text { in terms } \\
\text { of } \\
\text { number } \\
\text { of boats } \\
\text { in all } \\
\text { regions }\end{array}$} & \multirow{2}{*}{$\begin{array}{c}\text { Number } \\
\text { of } \\
\text { Firms }\end{array}$} & \multirow{2}{*}{$\begin{array}{c}\% \text { of } \\
\text { Total } \\
\text { Number }\end{array}$} & & & \\
\hline & & Number & $\begin{array}{c}(\text { See } \\
\text { Figure 1) }\end{array}$ & $\begin{array}{c}\text { Total } \\
\text { Units Sold }\end{array}$ & $\begin{array}{l}\% \text { of All } \\
\text { Sales }\end{array}$ & & & & No. & $\%$ & & & & & & & \\
\hline A & 3 & 2 & $\left\{\mathbf{S}_{1}, \mathrm{~S}_{2}\right\}$ & 6 & $29 \%$ & 3 & 58.5 & 15 & 8 & $9 \%$ & $29 \%$ & $\geq 15$ & 2 & $2 \%$ & $15-20$ & $12-15$ & $20 \%$ \\
\hline B & 2 & 3 & $\left\{\mathrm{~S}_{3}\right\}$ & 6 & $29 \%$ & 2 & 39.0 & 10 & 12 & $14 \%$ & $29 \%$ & $10-15$ & 9 & $10 \%$ & & & $30 \%$ \\
\hline c & 1 & 2 & $\left\{S_{4}\right\}$ & 2 & $10 \%$ & 1 & 19.5 & 5 & 8 & $9 \%$ & $10 \%$ & $4-10$ & 5 & $5 \%$ & $4-15$ & $15-20$ & \\
\hline D & 1 & 3 & $\left\{S_{s}\right\}$ & 3 & $15 \%$ & 1 & 19.5 & 5 & 12 & $14 \%$ & $15 \%$ & $4-10$ & 13 & $14 \%$ & & & Unknown \\
\hline E & $1 / 3$ & 12 & $\left\{\mathrm{~S}_{6}-\mathrm{S}_{13}\right\}$ & 4 & $19 \%$ & $1 / 3$ & 6.5 & $1^{2 / 3}$ & 48 & $55 \%$ & $19 \%$ & $<4$ & 64 & $69 \%$ & 3 or less & many & \\
\hline
\end{tabular}

'These are equilibrium sales deduced from an application of the competitive market theory. Other measures of size yield comparable percentage figures when applied uniformly across subjects.

${ }^{2}$ This refers to total units sold during low demand periods by all subjects in the class as dictated by an application of the competitive market theory.

${ }^{3}$ For each of the 93 firms responding to the questionnaires listed in Appendix D.1.1 in Smith (1976) additional sources such as DOT (1973) and Ferguson et al. (1975) were checked for clues to relative firm sizes. From these estimates a rough estimate of the numbers of "large" and "medium sized" firms were obtained. The number of small firms constitutes the residual.

${ }^{4}$ Various individuals in government, the industry and universities were asked about the total number of firms on the Mississippi and associated waterways and their relative sizes. The estimates reported here are a summary of their opinions. 
disadvantage of most market participants, especially the small ones, and helps only the large sellers. In this section we review in detail the data that lead to these conclusions.

The posted price policy causes higher prices (Table 4). After adjusting for the constant differences that existed across sessions, the mean price is higher in the posted price markets than in the negotiated price markets in every period. Combining periods 1 through 4 in sessions 1 and 4 , we see that the prices average near or below equilibrium, while in the posted price sessions 2 and 3, prices average $\$ .15$ above the equilibrium (which implies $6 \%$ above the $\$ 2.70$ ). When demand shifts up, both types of markets adjust, but prices remain relatively higher in the posted price markets, even though during these periods they are closer to the competitive equilibrium than are the prices in negotiated price markets. The fall in demand which occurs in period 9 is accompanied by a rapid adjustment in the negotiated price market relative to that in the posted price markets. Average price in the negotiated price market is $\$ .10$ above equilibrium (about $4 \%$ above the $\$ 2.70$ ), and in the posted price markets it is $\$ .23$ above equilibrium (about $9 \%$ above the $\$ 2.70)$. Prices in the posted price markets have a lower variance, but are uniformly higher.

Volume data are in Table 5. In any given period, with the exception of period 5, volume is always higher in the negotiated price markets than it is in the posted price markets. Furthermore, the differences are not small. In general, volume is from 20 to $30 \%$ higher in the negotiated price market.

This higher volume in the negotiated price market is attributable to two factors. First, the high prices fostered by the posted prices tend to choke off some demand. For the high demand elasticity case alone, one would expect that $5 \%$ higher prices would result in volume decreases of $15 \%$ or so. Hence, higher prices in the posted price markets account for part of the differences. Second, the volume in negotiated markets tends to be above the competitive equilibrium level. Small sellers are able to take advantage of the imperfect information conditions and sell high cost units at prices that would not exist under conditions of perfect information. Thus, the relatively high variance of prices in the negotiated markets as compared with the price variance in the posted price markets adds to the volume of the former and works to the advantage of the smaller, less efficient sellers.

The performance of laboratory markets can be described by a measure closely tied to traditional concepts of economic efficiency. Markets are efficient if the allocations are Pareto optimal or maximize consumers' plus producers' surpluses. Gains from exchange are exhausted. This occurs in laboratory markets if and only if the subjects maximize their combined profits from the experiment. The actual total profit subjects take as a percentage of the maximum possible total profit is a measure we shall call the market efficiency level or simply efficiency.

Market efficiency can be less than $100 \%$ for two reasons. First, some trades may not take place even though they are to the advantage of all parties. Various individuals may be willing and able to trade but fail to trade because they are unaware of each other, because strategic postures lead to no trades (monopoly and oligopoly are standard examples), or because technical complications prevent trading (e.g., the posted price institution reduces flexibility). Second, efficiency will be reduced if the wrong units get traded. Units with a high cost should not be sold if lower cost units go unsold as a result. The same applies on the demand side: units should not go to those who place a low value on them if the units can be placed where they have a higher value.

Table 6 summarizes the performance of the two market forms in terms of efficiency. Posted price markets are in general less efficient than negotiated price markets. Price posting causes prices to be set too high, thereby preventing some trades, and the posted prices reduce flexibility. This is reflected in the low efficiencies during the first low demand periods in which the combined average efficiency of the two posted price markets 
TABLE 4 Comparative Average Price Behavior

\begin{tabular}{|c|c|c|c|c|c|c|c|c|c|c|c|c|c|c|c|c|}
\hline \multirow[b]{3}{*}{ Period } & \multicolumn{16}{|c|}{ Session } \\
\hline & \multicolumn{4}{|c|}{$\begin{array}{c}1 \\
\text { (Negotiated Price) }\end{array}$} & \multicolumn{4}{|c|}{$\begin{array}{c}2 \\
\text { (Posted Price) }\end{array}$} & \multicolumn{4}{|c|}{$\begin{array}{c}3 \\
\text { (Posted Price) }\end{array}$} & \multicolumn{4}{|c|}{$\begin{array}{c}4 \\
\text { (Negotiated Price) }\end{array}$} \\
\hline & $\begin{array}{l}\text { Comp. } \\
\text { Equil. } \\
\$\end{array}$ & $\begin{array}{c}\text { Mean } \\
\$\end{array}$ & $\begin{array}{l}\text { Std. } \\
\text { Dev. }\end{array}$ & $\begin{array}{l}\text { Mean } \\
\text { Minus } \\
\text { Comp. } \\
\text { Equil. }\end{array}$ & $\begin{array}{c}\text { Comp. } \\
\text { Equil. } \\
\$\end{array}$ & $\begin{array}{c}\text { Mean } \\
\$\end{array}$ & $\begin{array}{l}\text { Std. } \\
\text { Dev. }\end{array}$ & $\begin{array}{l}\text { Mean } \\
\text { Minus } \\
\text { Comp. } \\
\text { Equil. }\end{array}$ & $\begin{array}{l}\text { Comp. } \\
\text { Equil. } \\
\$\end{array}$ & $\begin{array}{c}\text { Mean } \\
\$\end{array}$ & $\begin{array}{l}\text { Std. } \\
\text { Dev. }\end{array}$ & $\begin{array}{l}\text { Mean } \\
\text { Minus } \\
\text { Comp. } \\
\text { Equil. }\end{array}$ & $\begin{array}{c}\text { Comp. } \\
\text { Equil. } \\
\$\end{array}$ & $\begin{array}{c}\text { Mean } \\
\$\end{array}$ & $\begin{array}{l}\text { Std. } \\
\text { Dev. }\end{array}$ & $\begin{array}{l}\text { Mean } \\
\text { Minus } \\
\text { Comp. } \\
\text { Equil. }\end{array}$ \\
\hline 0 & 2.70 & 2.52 & .392 & -.18 & & & & & & & & & & & & \\
\hline 1 & 2.70 & 2.58 & .310 & -.12 & 6.40 & 6.42 & .385 & .02 & 3.80 & 3.82 & .349 & .02 & 7.50 & 7.51 & .416 & .01 \\
\hline 2 & 2.70 & 2.65 & .303 & -.05 & 6.40 & 6.56 & .246 & .16 & 3.80 & 4.01 & .171 & .11 & 7.50 & 7.53 & .332 & .03 \\
\hline 3 & 2.70 & 2.67 & .244 & -.03 & 6.40 & 6.61 & .193 & .21 & 3.80 & 4.01 & .094 & .21 & 7.50 & 7.57 & .296 & .07 \\
\hline 4 & 2.70 & 2.65 & .240 & -.05 & 6.40 & 6.56 & .114 & .16 & 3.80 & 3.98 & .055 & .18 & 7.50 & 7.63 & .280 & .13 \\
\hline 5 & 3.00 & 2.90 & .261 & -.10 & 6.70 & 6.60 & .162 & -.10 & 4.10 & 4.05 & .109 & -.05 & 7.80 & 7.75 & .347 & -.05 \\
\hline 6 & 3.00 & 2.91 & .295 & -.09 & 6.70 & 6.64 & .177 & -.06 & 4.10 & 4.06 & .110 & -.04 & 7.80 & 7.71 & .293 & -.09 \\
\hline 7 & 3.00 & 2.88 & .288 & -.12 & 6.70 & 6.71 & .137 & .01 & 4.10 & 4.07 & .092 & -.03 & 7.80 & 7.74 & .281 & -.06 \\
\hline 8 & & & & & 6.70 & 6.72 & .145 & .02 & 4.10 & 4.08 & .097 & -.02 & 7.80 & 7.77 & .265 & -.03 \\
\hline 9 & & & & & 6.40 & 6.71 & .110 & .31 & 3.80 & 4.03 & .077 & .23 & 7.50 & 7.59 & .210 & .09 \\
\hline 10 & & & & & 6.40 & 6.70 & .076 & .30 & 3.80 & 3.99 & .094 & .19 & 7.50 & 7.60 & .226 & .10 \\
\hline 11 & & & & & & & & & 3.80 & 3.98 & .059 & .18 & 7.50 & 7.61 & .253 & .11 \\
\hline 12 & & & & & & & & & 3.80 & 3.94 & .067 & .14 & 7.50 & 7.59 & .206 & .09 \\
\hline \multicolumn{17}{|l|}{ Average: } \\
\hline Low Demand & & 2.61 & & -.09 & & 6.54 & & .14 & & 3.96 & & .16 & & 7.56 & & .06 \\
\hline High Demand & & 2.90 & & -.10 & & 6.67 & & -.03 & & 4.07 & & -.03 & & 7.74 & & -.06 \\
\hline Low Demand & & & & & & 6.71 & & .31 & & 3.99 & & .19 & & 7.60 & & .10 \\
\hline
\end{tabular}




\begin{tabular}{|c|c|c|c|c|c|c|c|c|c|c|c|c|}
\hline \multirow[b]{3}{*}{ Period } & \multicolumn{12}{|c|}{ Session } \\
\hline & \multicolumn{3}{|c|}{1} & \multicolumn{3}{|c|}{2} & \multicolumn{3}{|c|}{3} & \multicolumn{3}{|c|}{4} \\
\hline & $\begin{array}{l}\text { Comp. } \\
\text { Eq. } \\
\text { Quant. }\end{array}$ & $\begin{array}{l}\text { Actual } \\
\text { Quant. }\end{array}$ & $\%$ & $\begin{array}{c}\text { Comp. } \\
\text { Eq. } \\
\text { Quant. }\end{array}$ & $\begin{array}{l}\text { Actual } \\
\text { Quant. }\end{array}$ & $\%$ & $\begin{array}{c}\text { Comp. } \\
\text { Eq. } \\
\text { Quant. }\end{array}$ & $\begin{array}{l}\text { Actual } \\
\text { Quant. }\end{array}$ & $\%$ & $\begin{array}{c}\text { Comp. } \\
\text { Eq. } \\
\text { Quant. }\end{array}$ & $\begin{array}{l}\text { Actual } \\
\text { Quant. }\end{array}$ & $\%$ \\
\hline 0 & 21 & 21 & 100 & & & & & & & & & \\
\hline 1 & 21 & 22 & 105 & 21 & 12 & 57 & 21 & 14 & 67 & 21 & 25 & 119 \\
\hline 2 & 21 & 24 & 114 & 21 & 14 & 67 & 21 & 17 & 81 & 21 & 24 & 114 \\
\hline 3 & 21 & 23 & 110 & 21 & 13 & 62 & 21 & 17 & 81 & 21 & 23 & 109 \\
\hline 4 & 21 & 23 & 110 & 21 & 18 & 86 & 21 & 17 & 81 & 21 & 22 & 105 \\
\hline 5 & 27 & 30 & 111 & 27 & 29 & 107 & 27 & 28 & 104 & 27 & 28 & 104 \\
\hline 6 & 27 & 30 & 111 & 27 & 28 & 104 & 27 & 29 & 107 & 27 & 30 & 111 \\
\hline 7 & 27 & 30 & 111 & 27 & 27 & 100 & 27 & 27 & 100 & 27 & 30 & 111 \\
\hline 8 & & & & 27 & 27 & 100 & 27 & 26 & 96 & 27 & 30 & 111 \\
\hline 9 & & & & 21 & 14 & 67 & 21 & 16 & 76 & 21 & 23 & 110 \\
\hline 10 & & & & 21 & 15 & 71 & 21 & 18 & 86 & 21 & 23 & 110 \\
\hline 11 & & & & & & & 21 & 17 & 81 & 21 & 22 & 105 \\
\hline \multirow[t]{5}{*}{12} & & & & & & & 21 & 17 & 81 & 21 & 23 & 110 \\
\hline & & & & & \multicolumn{3}{|c|}{ Negotiated } & \multicolumn{4}{|c|}{ Posted } & \\
\hline & & & & & Units & $\%$ & np. Eq. & Units & & $\%$ Com & & \\
\hline & \multirow{2}{*}{\multicolumn{3}{|c|}{$\begin{array}{l}\text { Average low demand periods } \\
\text { Average high demand periods }\end{array}$}} & \multicolumn{2}{|r|}{23} & \multicolumn{2}{|c|}{$109 \%$} & \multicolumn{2}{|l|}{15} & \multicolumn{2}{|c|}{$75 \%$} & \\
\hline & & & & \multicolumn{2}{|r|}{30} & \multicolumn{2}{|c|}{$110 \%$} & 28 & & \multicolumn{2}{|c|}{$103 \%$} & \\
\hline
\end{tabular}

is $78.4 \%$ as compared with $90 \%$ for the negotiated price markets. This is further emphasized by the very high efficiencies of the posted prices (a $97.6 \%$ average as compared with $92.5 \%$ for the negotiated markets) during the high demand periods. Prices were too high, but when the temporary demand increase occurred, they were just about right. The effects of lack of flexibility then become clear when demand again falls back to normal. Efficiency of the posted price markets averages $81.6 \%$ as compared with the $95.3 \%$ of the negotiated price market. Notice that the recovery of the negotiated price market is almost immediate, while the posted price market is only beginning to recover after four periods.

The final dimension of comparison between the two modes of organization is distribution. Relative to the competitive model, the posted price organization hurts the small traders, while the negotiated price market helps the small traders. The reason for the latter stems from the imperfect information in the negotiated price market. Small, less efficient sellers who would be excluded from the market under perfect circumstances manage to take advantage of the fact that buyers are not perfectly informed in the negotiated price market and make some sales. In the posted price markets, these same small sellers are almost completely excluded even though prices are higher than competitive levels. Exactly why the reduced total quantity seems to fall differentially on the small sellers is not obvious.

These distributional effects can be seen most easily in terms of the number of units sold by small sellers and in terms of relative profits. From Table 7, one sees that during low demand periods small sellers tend to sell twice as much in the negotiated price markets as they do under the posted price institutions. When prices are negotiated, the market share for small firms tends to be somewhat higher than the 19\% (low demand periods) and 30\% (high demand periods) predicted by the competitive mode. This reflects the advantage provided them by the incomplete information. On the other hand, their market share shrinks below the competitive level during low demand periods when the posted price policy is implemented. 
TABLE 6 Comparative Efficiency

\begin{tabular}{|c|c|c|c|c|}
\hline \multirow[b]{2}{*}{ Period } & \multicolumn{4}{|c|}{ Session } \\
\hline & $\begin{array}{c}1 \\
\text { (Negotiated } \\
\text { Price) }\end{array}$ & $\begin{array}{c}2 \\
\text { (Posted } \\
\text { Price) }\end{array}$ & $\begin{array}{c}3 \\
\text { (Posted } \\
\text { Price) }\end{array}$ & $\begin{array}{c}4 \\
\text { (Negotiated } \\
\text { Price) }\end{array}$ \\
\hline 0 & $81.6 \%$ & & & \\
\hline 1 & $98.6 \%$ & $69.8 \%$ & $71.7 \%$ & $83.0 \%$ \\
\hline 2 & $92.5 \%$ & $76.4 \%$ & $89.6 \%$ & $88.9 \%$ \\
\hline 3 & $93.4 \%$ & $70.7 \%$ & $79.2 \%$ & $90.1 \%$ \\
\hline 4 & $94.8 \%$ & $84.0 \%$ & $85.8 \%$ & $89.2 \%$ \\
\hline 5 & $93.2 \%$ & $98.6 \%$ & $94.8 \%$ & $87.7 \%$ \\
\hline 6 & $96.0 \%$ & $98.0 \%$ & $98.6 \%$ & $87.3 \%$ \\
\hline 7 & $95.2 \%$ & $97.7 \%$ & $96.2 \%$ & $90.1 \%$ \\
\hline 8 & & $99.4 \%$ & $97.2 \%$ & $95.8 \%$ \\
\hline 9 & & $71.2 \%$ & $81.6 \%$ & $96.2 \%$ \\
\hline 10 & & $80.7 \%$ & $85.8 \%$ & $95.8 \%$ \\
\hline 11 & & & $87.7 \%$ & $94.8 \%$ \\
\hline 12 & & & $92.4 \%$ & $94.3 \%$ \\
\hline \multicolumn{5}{|l|}{ Average First Low } \\
\hline Demand Periods & $92.2 \%$ & $75.2 \%$ & $81.6 \%$ & $87.8 \%$ \\
\hline \multicolumn{5}{|l|}{ Average High } \\
\hline Demand Periods & $94.8 \%$ & $98.4 \%$ & $96.7 \%$ & $90.2 \%$ \\
\hline \multicolumn{5}{|l|}{ Average Second Low } \\
\hline Demand Periods & & $76.0 \%$ & $87.1 \%$ & $95.3 \%$ \\
\hline Overall Average & $93.16 \%$ & $84.65 \%$ & $88.47 \%$ & $91.1 \%$ \\
\hline
\end{tabular}

TABLE 7 Units Sold by Smallest Twelve Sellers (Class E in Table 3)

\begin{tabular}{|c|c|c|c|c|c|c|c|c|}
\hline \multirow[b]{3}{*}{ Period } & \multicolumn{8}{|c|}{ Session } \\
\hline & \multicolumn{2}{|c|}{1} & \multicolumn{2}{|c|}{2} & \multicolumn{2}{|c|}{3} & \multicolumn{2}{|c|}{4} \\
\hline & Number & $\begin{array}{c}\% \text { Total } \\
\text { Units } \\
\text { Sold }\end{array}$ & Number & $\begin{array}{c}\% \text { Total } \\
\text { Units } \\
\text { Sold }\end{array}$ & Number & $\begin{array}{c}\% \text { Total } \\
\text { Units } \\
\text { Sold }\end{array}$ & Number & $\begin{array}{c}\text { \% Total } \\
\text { Units } \\
\text { Sold }\end{array}$ \\
\hline 0 & 5 & 25 & & & & & & \\
\hline 1 & 5 & 22 & 1 & 8 & 2 & 14 & 9 & 36 \\
\hline 2 & 3 & 14 & 2 & 14 & 2 & 12 & 6 & 25 \\
\hline 3 & 5 & 22 & 2 & 15 & 4 & 24 & 6 & 26 \\
\hline 4 & 5 & 22 & 3 & 18 & 5 & 28 & 5 & 23 \\
\hline 5 & 11 & 37 & 10 & 34 & 10 & 36 & 7 & 25 \\
\hline 6 & 11 & 37 & 9 & 32 & 10 & 35 & 10 & 33 \\
\hline 7 & 9 & 30 & 9 & 33 & 8 & 30 & 10 & 33 \\
\hline 8 & & & 8 & 30 & 8 & 30 & 10 & 33 \\
\hline 9 & & & 4 & 24 & 2 & 13 & 5 & 22 \\
\hline 10 & & & 1 & 6 & 2 & 10 & 5 & 22 \\
\hline 11 & & & & & 4 & 24 & 4 & 19 \\
\hline 12 & & & & & 2 & 11 & 5 & 22 \\
\hline Average Low Demand & & & & & & & & \\
\hline Periods & 4.6 & 21 & 2 & 14 & 3.25 & 20 & 6.5 & 28 \\
\hline Average High Demand & & & & & & & & \\
\hline Periods & 10.3 & 35 & 6.5 & 32 & 9 & 33 & 9.3 & 31 \\
\hline Average Low Demand & & & & & & & & \\
\hline Periods & & & 2.5 & 15 & 2.5 & 15 & 4.8 & 21 \\
\hline
\end{tabular}


TABLE 8 Profits in Dollars* Earned by Smallest Twelve Sellers (Class E in

Table 3) and Largest Two Sellers (Class A in Table 3)

\begin{tabular}{|c|c|c|c|c|c|c|c|c|}
\hline \multirow[b]{3}{*}{ Period } & \multicolumn{4}{|c|}{$\begin{array}{l}\text { Small Sellers } \\
\text { Class E }\end{array}$} & \multicolumn{4}{|c|}{$\begin{array}{c}\text { Large Sellers } \\
\text { Class A }\end{array}$} \\
\hline & \multicolumn{4}{|c|}{ Session } & \multicolumn{4}{|c|}{ Session } \\
\hline & 1 & 2 & 3 & 4 & 1 & 2 & 3 & 4 \\
\hline 0 & 2.75 & & & & 2.88 & & & \\
\hline 1 & 2.13 & 1.25 & 2.25 & 3.63 & 2.38 & 4.25 & 4.63 & 4.13 \\
\hline 2 & 1.88 & 1.75 & 1.50 & 3.68 & 3.55 & 9.25 & 7.00 & 4.75 \\
\hline 3 & 1.80 & 2.50 & 2.50 & 4.53 & 3.40 & 7.38 & 9.38 & 6.00 \\
\hline 4 & 1.63 & 3.38 & 2.35 & 2.88 & 4.88 & 6.75 & 5.08 & 7.00 \\
\hline 5 & 5.13 & 3.88 & 4.75 & 7.38 & 6.30 & 9.75 & 9.70 & 7.75 \\
\hline 6 & 5.60 & 5.48 & 4.00 & 7.88 & 5.13 & 9.75 & 10.80 & 8.13 \\
\hline 7 & 3.13 & 6.58 & 3.98 & 7.50 & 7.13 & 10.88 & 10.80 & 8.75 \\
\hline 8 & & 5.98 & 3.75 & 7.38 & & 10.88 & 9.25 & 9.00 \\
\hline 9 & & 3.50 & 1.25 & 2.63 & & 10.75 & 7.75 & 8.50 \\
\hline 10 & & 1.00 & .50 & 3.68 & & 5.00 & 10.65 & 7.75 \\
\hline 11 & & & 1.88 & 2.63 & & & 8.63 & 6.63 \\
\hline 12 & & & .23 & 2.78 & & & 9.30 & 5.88 \\
\hline
\end{tabular}

${ }^{*}$ Each $1 \phi$ profit in experiment $=2.5 \phi$ in U.S. currency.

Profit figures appear in Table 8. In only two periods (periods 4 and 9) are the profits of the small sellers in a posted price session higher than their profits in the corresponding periods of negotiated price sessions, and in all but four periods small sellers' profits in negotiated price markets dominate their profits in the posted price markets. On average, small sellers made $\$ 4.04$ per period when prices were negotiated, but this shrinks to $\$ 2.90$ in the posted price markets. The shift from negotiated prices to posted prices resulted in a $28 \%$ reduction in income for small sellers. On the other hand, the largest two sellers were helped by the posted price policy. For them profits in the posted price markets dominate profits in the negotiated price markets in almost every period. These two large sellers made $\$ 6.00$ per period on average in the negotiated price markets, but their profit increased by $42 \%$ to $\$ 8.53$ with the change to a posted price policy.

Much of the distributional effect can be summarized by estimates of the percentage of small suppliers that would have been driven from the market by a price posting policy. The annual average volume per period of all small firms in the laboratory market was 6.2 units in the negotiated price market and 3.6 units in the posted price market. ${ }^{8}$ Even at the higher prices generated by the posting policy, the low volume would have been sufficient to cover the annual cost of only about $60 \%$ of the small firms that could successfully operate in the negotiated price market. Thus, the price posting policy would have eliminated about $40 \%$ of the small firms.

\section{Conclusions}

- In laboratory markets that have many of the essential economic features of the barge industry, rate filing policies have very pronounced and undesirable effects. They cause higher prices, lower volume, a reduced efficiency, and they hurt the small participants.

$$
\begin{aligned}
& { }^{8} .8\left(\frac{4.6+6.5+4.8}{3}\right)+.2\left(\frac{10.3+9.3}{2}\right)=6.2 \\
& .8\left(\frac{2+3.25+2.5+2.5}{4}\right)+.2\left(\frac{6.5+9}{2}\right)=3.6
\end{aligned}
$$


The experimental results are translated to the industry level and presented together with the actual industrial data in Figure 2 and Table 9. ${ }^{9}$ Prices in posted price markets are from 5 to $9 \%$ above prices in the negotiated price markets. Volume during low demand periods is considerably less, by 25 to $30 \%$, for posted price markets. During high demand periods, posted prices and volume appear to be in line with competitive theory, but this is actually an illusion. The posted prices were excessively high at the time of a demand increase; and because the institution is so cumbersome and slow in adjusting, prices stayed "about right" for the high demand periods.

The high prices in posted price markets are accompanied by a loss in efficiency of 5 to $15 \%$. The combined effect is a social loss and a diversion of 20 to $30 \%$ of the annual grain traffic, worth about $\$ 44$ million, to trucking and railroads.

This loss of volume falls most heavily upon the small sellers. As many as $40 \%$ could be forced out of business. Naturally, since prices are generally higher, all shippers are hurt by the posted price policy. Ironically, the policy would hurt most those whom some claim it would help.

With these conclusions the big question remains: To what extent can one rely upon the experiences generated in simple laboratory markets as indicators of what will happen in the larger, more complicated markets? Experimentalists in the physical sciences face the same type of question, and it cannot be answered without actually implementing the policy in the barge industry. Similarly, laboratory results in the physical sciences must be given field tests before reliability can be ascertained. From a scientific point of view, we have solid evidence only that price posting markets do not necessarily operate better than negotiated price markets under the parametric conditions we considered. From a

FIGURE 2

MONTHLY PRICE-VOLUME DATA: INDUSTRY AND EXPERIMENTAL AT INDUSTRIAL SCALE

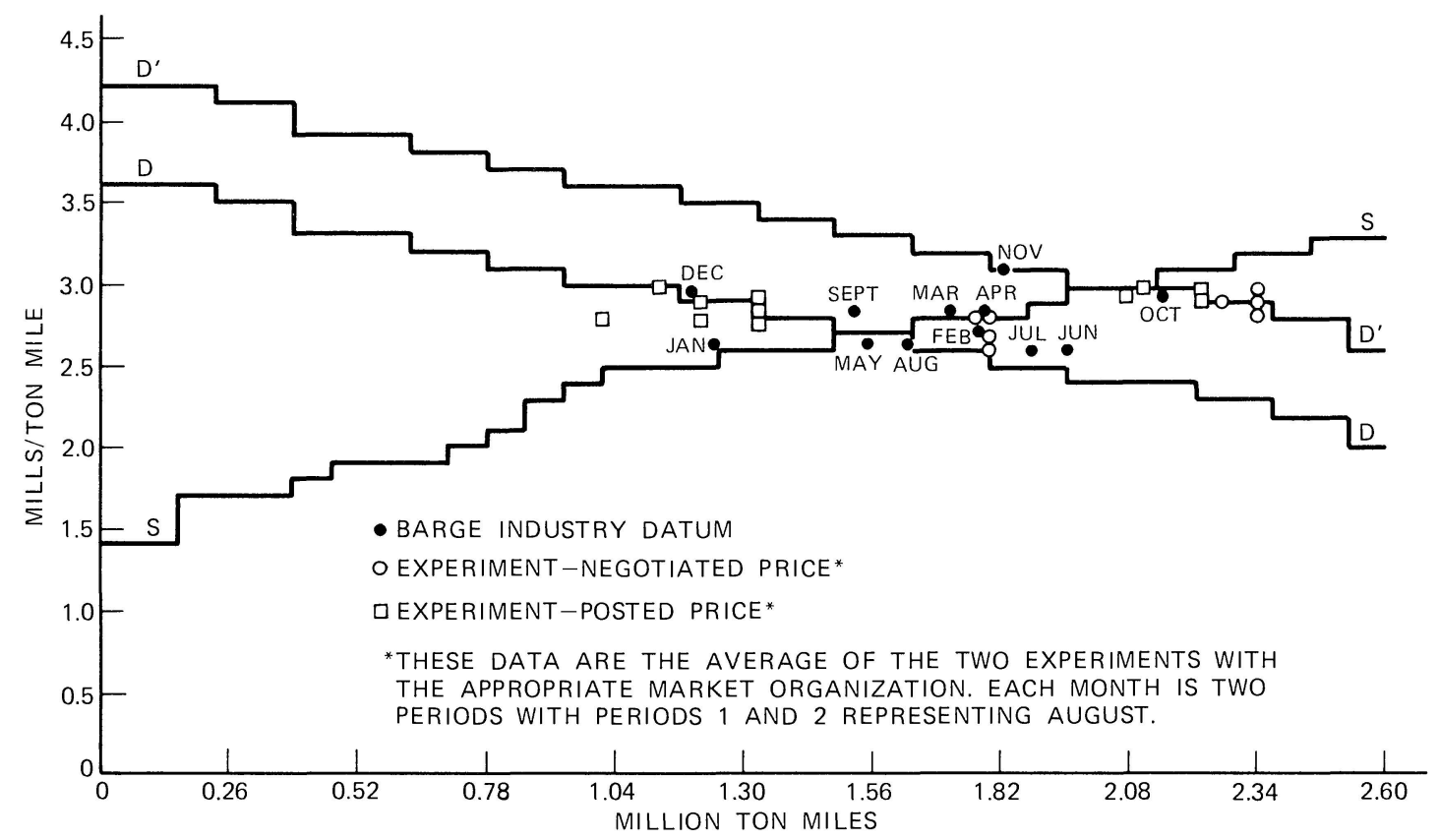

${ }^{9}$ Each experimental period represents two weeks so that a price-volume pair of experimental data, representing a month, in the illustration is the average price over two experimental periods and the total volume over the two periods. The volume was transformed to industrial scale by application of the transformation introduced in Section 4. 
Session

\begin{tabular}{|c|c|c|c|c|c|c|c|c|c|}
\hline \multirow[b]{3}{*}{$\begin{array}{c}\text { Experimental } \\
\text { Period } \\
\text { Number }\end{array}$} & \multirow[b]{3}{*}{$\begin{array}{c}\text { Corresponding } \\
\text { Month }\end{array}$} & \multicolumn{8}{|c|}{ Session } \\
\hline & & \multicolumn{2}{|l|}{1} & \multicolumn{2}{|l|}{2} & \multicolumn{2}{|l|}{3} & \multicolumn{2}{|l|}{4} \\
\hline & & $\begin{array}{c}\text { Volume* Million } \\
\text { Ton Miles per } \\
\text { Two Weeks }\end{array}$ & $\begin{array}{l}\text { Av.* } \\
\text { Price }\end{array}$ & $\begin{array}{l}\text { Volume Million } \\
\text { Ton Miles per } \\
\text { Two Weeks }\end{array}$ & $\begin{array}{l}\text { Av. } \\
\text { Price }\end{array}$ & $\begin{array}{l}\text { Volume Million } \\
\text { Ton Miles per } \\
\text { Two Weeks }\end{array}$ & $\begin{array}{l}\text { Av. } \\
\text { Price }\end{array}$ & $\begin{array}{l}\text { Volume Million } \\
\text { Ton Miles per } \\
\text { Two Weeks }\end{array}$ & $\begin{array}{l}\text { Av. } \\
\text { Price }\end{array}$ \\
\hline 0 & & 819 & 2.52 & & & & & & \\
\hline 1 & Aug. & 858 & 2.58 & 468 & 2.72 & 546 & 2.72 & 975 & 2.71 \\
\hline 2 & & 936 & 2.65 & 546 & 2.86 & 663 & 2.91 & 936 & 2.73 \\
\hline 3 & Sept. & 897 & 2.67 & 507 & 2.91 & 663 & 2.91 & 897 & 2.77 \\
\hline 4 & & 897 & 2.65 & 702 & 2.86 & 663 & 2.88 & 858 & 2.83 \\
\hline 5 & Oct. \#1 & 1170 & 2.90 & 1131 & 2.90 & 1092 & 2.95 & 1092 & 2.95 \\
\hline 6 & & 1170 & 2.91 & 1092 & 2.94 & 1131 & 2.96 & 1170 & 2.91 \\
\hline 7 & Oct. \#2 & $1170^{* *}$ & $2.88^{*}$ & 1053 & 3.01 & 1053 & 2.97 & 1170 & 2.94 \\
\hline 8 & & & & 1053 & 3.02 & 1014 & 2.98 & 1170 & 2.97 \\
\hline 9 & Jan. & & & 546 & 3.01 & 624 & 2.93 & 897 & 2.79 \\
\hline 10 & & & & 585 & 3.00 & 702 & 2.89 & 897 & 2.80 \\
\hline 11 & Feb. & & & & & 663 & 2.88 & 858 & 2.81 \\
\hline 12 & & & & & & 663 & 2.84 & 897 & 2.79 \\
\hline
\end{tabular}

* The low demand conditions lasted for five periods during the first session and the high demand conditions lasted only three periods. The first period of the first session is regarded here as a learning period. The remaining periods were not run because of logistical difficulties the first evening.

** These figures are simply repeated to get numbers for a second two weeks for October \#2 for session no. 1. 
policy point of view, this evidence presumably shifts the burden of proof to the price posting advocates, who must now identify the specific features of the barge industry which, if incorporated in the experiment, would reverse the conclusions.

\section{Appendix}

- Instructions are as in the appendix to Plott and Smith (1978) with this section replacing the corresponding section.

a Market organization. The market for this commodity is organized as follows. We open the market for a trading period (a trading "day"). The period lasts for minutes. Any trader is free to telephone any other trader at any time during the period to discuss trade possibilities. When a buyer and a seller agree to trade a single unit at a price, a contract is in order. (Note that trading is permitted only between a buyer and a seller.) Each party is to say to the other the following: "I now have a contract at (price) with trader (number) at (time)." A contract is consummated only after both parties have made the above statement (i.e., there is no binding contract if the formal statement has not been said). All contracts are for a single unit.

After a contract is made, the buyer and seller will record the time of the contract and the contract price to be included in their earnings on the record sheets. There are likely to be many unsuccessful discussions, but you are free to keep trying, and, as a buyer or seller, you are free to make as much profit as you can.

Are there any questions?

\section{$\square$ Final observations}

1. Each individual has a large envelope. All papers, instructions, records, etc. should be put into this envelope. Leave the envelope with us before leaving tonight. Take nothing home with you.

2. We are able to advise you a little on making money. First, you should remember that pennies add up. Over many trades and a long period of time very small amounts earned on individual trades can add up to a great deal of money. Second, you should not expect your earnings to be steady. You will have some good periods and some bad periods. There will be some good nights and some bad. During bad times try not to become frustrated. Just stay in there and keep trying and earn what you can. It all adds up.

Some people rush to trade. Others find it advantageous to "shop" or spread their trading over the period. We are unaware of any particular "best" strategies and suggest that you adapt accordingly.

3. You are free to call anyone you wish, say anything you want, and gather any information you can from any source you wish. However, under no circumstances may you mention anything about activities which might involve you and other participants after the experiment (i.e., no physical threats, deals to split up afterwards, or leading questions). Furthermore, agreements to fix prices or otherwise restrain trade are strictly prohibited.

4. Each individual will be paid in private. Your earnings are strictly your own business.

(Added for Posted Price.)

During the next periods each seller is required to make all his sales at the fixed price of his choice. He must set his price (entered on the appropriate line below) before the period starts and leave it there until the period ends.

Buyers are free to buy all they want (or can) from any seller. 


\section{References}

CARR, B.B. "Barge Transportation-Energizer of Production and Marketing." Journal of the Waterways and Harbors Division, Proceedings of the American Society of Civil Engineers, Vol. 95, No. WW2 (May 1969), pp. 163-173.

Ferguson, A.R., HABIB, V., AND Smith, D.M. "The Gross Revenue Impact on Railroads in the CONRAIL Region of Placing User Charges on Barges." Washington, D.C.: Public Interest Economics Center, July 1975.

FRIEDLAENDER, A.F. The Dilemma of Freight Transport Regulation. Brookings Institution, Washington, D.C., 1969.

Gill, C.G. AND Whitten, H.O. "Development of Transport Cost Functions." Mimeographed. Annandale, Va.: Herbert O. Whitten and Associates, July 1976.

Hong, J.T. AND Plott, C.R. "Implications of Rate Filing for Domestic Dry Bulk Transportation on Inland Waters: An Experimental Approach.” Social Science Working Paper No. 164. Pasadena: California Institute of Technology, July 1977.

Howe, C.W., et al. Inland Waterway Transportation Studies in Public and Private Management and Investment Decisions. Washington, D.C.: Resources for the Future, Inc., 1969.

Plott, C.R. "The Application of Laboratory Experimental Methods to Public Choice" in C. Russell, ed., Collective Decision Making: Applications from Public Choice Theory, Washington, D.C.: Resources for the Future, 1979.

- AND Smith, V.L. "An Experimental Examination of Two Exchange Institutions." Review of Economic Studies, Vol. 45 (February 1978), pp. 133-153.

Smith, V.L. "Experimental Economics: Induced Value Theory." American Economic Review, Vol. 66, No. 2 (May 1976), pp. 274-279.

United States Department of Transportation. "The Barge Mixing Rule Problem: A Study of Economic Regulation of Domestic Dry Bulk Commodity Transportation." Washington, D.C.: U.S. Government Printing Bureau, March 1973.

Williams, F. "Effect of Market Organization on Competitive Equilibrium: The Multiunit Case." Review of Economic Studies, Vol. 40 (January 1973), pp. 97-113. 